\title{
T cell-mediated Fas-induced keratinocyte apoptosis plays a key pathogenetic role in eczematous dermatitis
}

\author{
Axel Trautmann, ${ }^{1}$ Mübeccel Akdis, ${ }^{1}$ Daniela Kleemann, ${ }^{2}$ Frank Altznauer, ${ }^{1}$ \\ Hans-Uwe Simon, ${ }^{1}$ Thomas Graeve, ${ }^{3}$ Michaela Noll, ${ }^{3}$ Eva-B. Bröcker, ${ }^{4}$ \\ Kurt Blaser, ${ }^{1}$ and Cezmi A. Akdis ${ }^{1}$ \\ ${ }^{1}$ Swiss Institute of Allergy and Asthma Research (SIAF), Davos, Switzerland \\ ${ }^{2}$ High-altitude Clinic of Zürich, Davos-Clavadel, Switzerland \\ ${ }^{3}$ Fraunhofer Institute for Interfacial Engineering and Biotechnology, Stuttgart, Germany \\ ${ }^{4}$ Department of Dermatology, University of Würzburg, Würzburg, Germany \\ Address correspondence to: Axel Trautmann, Swiss Institute of Allergy and Asthma Research (SIAF), Obere Strasse 22, \\ CH-7270 Davos, Switzerland. Phone: 41-81-4100848; Fax: 41-81-4100840; E-mail: atraut@siaf.unizh.ch.
}

Received for publication December 20, 1999, and accepted in revised form May 9, 2000.

\begin{abstract}
Clinical and histologic similarities between various eczematous disorders point to a common efferent pathway. We demonstrate here that activated $T$ cells infiltrating the skin in atopic dermatitis $(\mathrm{AD})$ and allergic contact dermatitis (ACD) induce keratinocyte (KC) apoptosis. KCs normally express low levels of Fas receptor (FasR) that can be substantially enhanced by the presence of IFN- $\gamma$. KCs are rendered susceptible to apoptosis by IFN- $\gamma$ when FasR numbers reach a threshold of approximately 40,000 per KC. Subsequently, KCs undergo apoptosis induced by anti-FasR mAb's, soluble Fas ligand, supernatants from activated T cells, or direct contact between T cells and KCs. Apoptotic KCs show typical DNA fragmentation and membrane phosphatidylserine expression. $\mathrm{KC}$ apoptosis was demonstrated in situ in lesional skin affected by $\mathrm{AD}, \mathrm{ACD}$, and patch tests. Using numerous cytokines and anticytokine neutralizing mAb's, we found no evidence that cytokines other than IFN- $\gamma$ participate in this process. In addition, apoptosis-inducing pathways other than FasR triggering were ruled out by blocking T cell-induced KC apoptosis by caspase inhibitors and soluble Fas-Fc protein. Responses of normal human skin and cultured skin equivalents to activated $\mathrm{T}$ cells demonstrated that $\mathrm{KC}$ apoptosis caused by skin-infiltrating $\mathrm{T}$ cells is a key event in the pathogenesis of eczematous dermatitis.
\end{abstract}

J. Clin. Invest. 106:25-35 (2000).

\section{Introduction}

Eczematous disorders account for a large proportion of all skin disease, and constitute a major health problem worldwide. Eczematous dermatitis is characterized histologically by pathologic changes in the epidermis and a predominantly mononuclear cell infiltrate. The clinical features include itching, redness, papules, vesicles, and scaling. Because T cells constitute a large population of cellular infiltrate in eczematous dermatitis, a dysregulated, cytokinemediated response of the immune system appears to be an important pathogenetic factor. Keratinocytes (KCs) within eczematous lesions exhibit an unusual expression of MHC class II antigens (e.g., HLA-DR), ICAM-1 (CD54), and IFN- $\gamma$ inducible protein-10, all of which are strongly induced by $\operatorname{IFN}-\gamma(1,2)$. ICAM1 mediates strong adhesion between T cells and KCs (3). Thus it seems probable that cytokines and cellsurface molecules of the accumulated skin-infiltrating $\mathrm{T}$ cells affect KCs in situ.

Atopic dermatitis (AD) is a chronic skin disease manifested by eczematous skin lesions that affects more than $10 \%$ of children $(4,5)$. Lesional atopic skin clinically and histologically resembles allergic contact dermatitis (ACD), which may be mediated by predominant expression of the type 1 cytokine IFN- $\gamma(6,7)$. In AD, circulating allergen-specific memory/effector $\mathrm{T}$ cells expressing cutaneous lymphocyte-associated antigen homing receptor have been demonstrated to be activated in vivo, to regulate IgE by an IL-13-dominated cytokine pattern, and to delay eosinophil apoptosis by IL-5 (8-10). Allergen-specific T cells from skin and peripheral blood have shown a profound dysregulation of IL-4 and IFN- $\gamma$ secretion, with an overproduction of IL-4 and reduced IFN- $\gamma$ secretion in AD $(11,12)$. However, studies focused on the intralesional cytokine production revealed higher IFN- $\gamma$ production than occurs in T cells from peripheral blood $(13,14)$. A sequential activation of type 2 and type 1 T cells in the pathogenesis of AD was therefore proposed (15-17). Recent results from a murine model of eczematous dermatitis suggests that both the type 2 cytokines IL- 4 and IL-5, and the type 1 cytokine IFN- $\gamma$ play important roles in the inflammation of the skin (18). Furthermore, injection of IFN- $\gamma$ into the skin of human volunteers demonstrated that this cytokine can induce transient skin inflammation (19). Moreover, transgenic mice expressing IFN- $\gamma$ in the epidermis have developed eczema spontaneously, and showed an increased contact hypersensitivity reaction (20). 
In this study, we demonstrated that $\mathrm{KC}$ apoptosis is a major mechanism in the pathogenesis of eczematous disorders. T cells infiltrating the skin upregulate Fas receptor (FasR) on $\mathrm{KCs}$, render them susceptible to apoptosis by IFN- $\gamma$, and induce apoptosis by Fas ligand (FasL) expressed on the T-cell surface.

\section{Methods}

Subjects. Patients with acute AD, chronic AD, and acute ACD were included in the study. They were not receiving any systemic therapy for at least 2 weeks before biopsy and patch testing with house dust mite and nickel. AD patients had definite AD, diagnosed according to standard criteria (21). ACD for nickel was originally diagnosed by epicutaneous patch testing. The patch test reactions were $2+$ according to the International Contact Dermatitis Research Group, showing erythema, induration, papules, and vesicles. Incisional skin biopsies were taken from lesional AD skin (acute $\mathrm{AD}$, four biopsies; chronic $\mathrm{AD}$, five biopsies), atopy patch tests (two biopsies), and ACD patch tests (four biopsies). Control skin was obtained from three healthy, nonatopic individuals. Informed consent was obtained from all subjects, and the study was approved by the Ethical Committee of Davos, Switzerland.

Reagents and $A b s$. Recombinant human IL-12 and IL-5 were purchased from PharMingen (San Diego, California, USA). Recombinant human IL-13 was purchased from PeproTech Inc. (Rocky Hill, New Jersey, USA). Recombinant human IFN- $\gamma$, IL-2, IL-4, and TNF- $\alpha$ came from Novartis Pharmaceuticals (Basel, Switzerland). Ethidium bromide and PMA were purchased from Sigma Chemical Co. (St. Louis, Missouri, USA). Ionomycin was purchased from Calbiochem-Novabiochem Corp. (San Diego, California, USA). The mAb's for flow cytometry were purchased from Beckman Coulter Intl. SA (Nyon, Switzerland), Immunotech (Marseilles, France), or PharMingen. Anti-CD14, antiCD16, anti-CD19, and anti-CD45RA magnetic microbeads for magnetic activated cell sorting (MACS) were from Miltenyi Biotec (Bergisch Gladbach, Germany). Anti-CD2 (4B2 and 6G4) and anti-CD28 (15E4) $m A b$ 's were from the Red Cross Blood Transfusion Service (Amsterdam, the Netherlands). Anti-CD3 came from clone CRL8001, obtained from American Type Culture Collection (Manassas, Virginia, USA). The activating, cross-linking anti-FasR mAb $\mathrm{CH}-11$ and the anti-FasR mAb ZB4 (which inhibits apoptosis induced by $\mathrm{CH}-11)$ were purchased from Immunotech. The blocking anti-IFN- $\gamma$ receptor- $\alpha$ chain (CD119) $\mathrm{mAb}$ was purchased from Genzyme Pharmaceuticals (Cambridge, Massachusetts, USA). Neutralizing anti-IL-4 mAb's (8F12 and 3H4) and IFN- $\gamma$ mAb $45-15$ were provided by Novartis Pharmaceuticals. Anti-IL-13 mAb's (JES8-5A2 and JES10-2F9) and the mutant IL-4 antagonist (Y124D) with IL-13- and IL-4-inhibitory activity were provided by DNAX Research Institute (Palo Alto, California, USA). The recombinant human soluble FasL and Fas-Fc protein (inhibiting the activity of FasL) were purchased from Alexis Corp. (San Diego, California, USA). The enzyme inhibitor (Z)-Val-Ala-DL-Asp-fluoromethylketone (Z-VAD-FMK) was from Bachem AG (Bubendorf, Switzerland).

KC culture. Primary human KCs were obtained from punch biopsies from nonlesional, nonmedicated gluteal skin. The skin was split overnight in a PBS solution of sucrose and trypsin (0.1\% sucrose, $0.25 \%$ trypsin, $1 \mathrm{mM}$ EDTA; all reagents were from Sigma Chemical Co.) at $4^{\circ} \mathrm{C}$. Epidermal sheets were removed from the dermis, and $\mathrm{KC}$ cell suspensions were cultured in a fully supplemented $(5 \mu \mathrm{g} / \mathrm{mL}$ bovine insulin, $0.5 \mu \mathrm{g} / \mathrm{mL}$ hydrocortisone, $0.1 \mathrm{ng} / \mathrm{mL}$ human recombinant EGF, 30 $\mu \mathrm{g} / \mathrm{mL}$ bovine pituitary extract, $100 \mu \mathrm{g} / \mathrm{mL}$ gentamicin, and $100 \mathrm{ng} / \mathrm{mL}$ amphotericin B), low calcium (0.15 mM $\mathrm{Ca}^{2+}$ ), serum-free KC growth medium (Clonetics Corp., San Diego, California, USA). Hydrocortisone and antibiotics were removed from the culture medium for the duration of experiments. All cell cultures were incubated at $37^{\circ} \mathrm{C}$ in a humidified atmosphere with $5 \% \mathrm{CO}_{2}$. $\mathrm{KCs}$ that had undergone at least three passages were grown in either 6-well Transwell plates, 6-well plates, or 96-well flat-bottom plates (all from Corning-Costar Corp., Cambridge, United Kingdom) for different experiments. Single-cell suspensions of KCs were prepared by the addition of $0.025 \%$ trypsin and $0.01 \%$ EDTA for $5-15$ minutes at $37^{\circ} \mathrm{C}$, neutralized by adding $10 \%$ FCS (Sera-Lab Ltd., Sussex, United Kingdom).

Isolation of $C D 45 R A^{+}$and $C D 45 R O^{+} T$ cells from peripheral blood and differentiation and characterization of $\mathrm{CD}^{+}$and $C D 8^{+}$type 1 and type 2 T cells. After 2-3 weeks of KC culture, PBMCs from the same patient were isolated by Ficoll (Biochrom KG, Berlin, Germany) density gradient centrifugation of peripheral venous blood. Cells were washed and resuspended in DMEM supplemented with $10 \mathrm{mM}$ HEPES (both from Life Technologies AG, Basel, Switzerland), 5 mM EDTA, 2\% FCS, $100 \mathrm{U} / \mathrm{mL}$ glutamine, and $100 \mu \mathrm{g} / \mathrm{mL}$ streptomycin (both from Life Technologies $\mathrm{AG}) . \mathrm{CD}_{45 \mathrm{RA}^{+}}$and $\mathrm{CD} 45 \mathrm{RO}^{+} \mathrm{T}$ cells were isolated with the MACS system according to the instructions of the manufacturer (Miltenyi Biotec). In brief, anti-CD14- and anti-CD19-depleted cells were incubated with MACS microbeads coated with anti-CD45RA and anti-CD16 $\mathrm{mAb}$, and the T-cell fractions were recovered by sequential elution from the MACS column. $\mathrm{CD}^{+}$and $\mathrm{CD}^{+}$ type 1 and type $2 \mathrm{~T}$ cells were generated from naive CD45RA ${ }^{+} \mathrm{T}$ cells isolated from cord blood. The cells were incubated in the presence of either IL-12 $(10 \mathrm{ng} / \mathrm{mL})$ and neutralizing anti-IL-4 mAb $(10 \mu \mathrm{g} / \mathrm{mL}$ ) (for the generation of type $1 \mathrm{~T}$ cells $)$ or IL-4 $(25 \mathrm{ng} / \mathrm{mL})$ and neutralizing anti-IL-12 mAb $(10 \mu \mathrm{g} / \mathrm{mL}$ ) (for the generation of type 2 T cells) in the presence of IL-2 $(20 \mathrm{ng} / \mathrm{mL})$ for 12 days. The $T$ cells were stimulated with a combination of mAb's $(0.5 \mu \mathrm{g} / \mathrm{mL}$ anti-CD2, $1.0 \mu \mathrm{g} / \mathrm{mL}$ anti-CD3, and 0.5 $\mu \mathrm{g} / \mathrm{mL}$ anti-CD28). Supernatants were harvested after 3 days for cytokine measurements. Phenotypes of type 1 and type $2 \mathrm{~T}$-cell subsets were verified for cytokine production by ELISA of culture supernatants and intracellular cytokine flow cytometry analysis. 
KC-T cell cocultures. CD45RO ${ }^{+} \mathrm{T}$ cells and differentiated type 1 and type $2 \mathrm{~T}$ cells were stimulated with a combination of anti-CD2, anti-CD3, and anti-CD28 mAb's, plate-bound anti-CD3 $(10 \mu \mathrm{g} / \mathrm{mL})$, or PMA (10 $\mathrm{ng} / \mathrm{mL})$ and ionomycin $(0.5 \mu \mathrm{M})$ for 24 hours, and then washed twice before coculture with KCs. In some experiments, type $2 \mathrm{~T}$ cells were stimulated in the presence of IL-12 (10 ng/mL). For studying the effects of T cells on KCs, T-cell supernatants were collected, diluted 50\%, and added to KCs in 96-well plates. For coculture experiments, KCs were cultured in 96-well plates in the presence or absence of purified $\mathrm{T}$ cells at different ratios (generally $10^{4} \mathrm{~T}$ cells and $3 \times 10^{4} \mathrm{KCs}$, ratio $1: 3$ ). For further coculture experiments, KCs and T cells were cultured in 6-well Transwell plates (Corning-Costar Corp.). The Transwells consist of a lower and an upper compartment, which are separated by a $10-\mu \mathrm{m}$-thick polycarbonate membrane with $0.4-\mu \mathrm{m}$ pores. $\mathrm{KCs}(3 \times$ $10^{5}$ ) were transferred into the lower culture well and $\mathrm{T}$ cells $\left(10^{5}\right)$ were added to the upper compartment.

Flow cytometry analysis. IFN- $\gamma$ receptor and IFN$\gamma$-induced FasR (CD95) expression was determined on primary human KCs with anti-IFN- $\gamma$ receptor and FasR mAb (ZB4), followed by phycoerythrin-conjugated (PE-conjugated) anti-mouse IgG. For phenotyping of effector $\mathrm{T}$ cell subsets, $5 \times 10^{5}$ cells were incubated at $4^{\circ} \mathrm{C}$ for 30 minutes, and then sequentially stained with anti-CD4-, anti-CD8- or CD45RO-PE. Stained cells were fixed in $2 \%$ paraformaldehyde. PEconjugated mouse IgG1 was used as control. After washing, cells were analyzed on an EPICS XL-MCL flow cytometer (Beckman Coulter Intl. SA). The purity of the T-cell populations ranged from $90 \%$ to $96 \%$. FasR counting on KC surfaces was done by indirect immune fluorescence staining with $50 \mu \mathrm{g} / \mathrm{mL}$ antiFasR mAb (ZB4) followed by FITC-conjugated antimouse IgG (DAKO A/S, Glostrup, Denmark). Beads coated with known amounts of mouse mAb's were used as standards (DAKO A/S) (22). The receptor molecules per cell were probably counted in lower numbers with this method than the classical Scatchard blot receptor determination would yield.

Viability and apoptosis detection. The KC viability after exposure to anti-FasR mAb, soluble FasL, or after coculture with $\mathrm{T}$ cells was routinely evaluated by means of ethidium bromide $(1 \mu \mathrm{M})$ uptake and flow cytometry. Membrane phosphatidylserine redistribution from the inner to the outer membrane leaflet takes place in apoptotic cells. Annexin V is a phosphatidylserine binding protein used to detect apoptotic cells. The technique was performed according to Vermes et al. (23). Briefly, cells were incubated with $1.0 \mu \mathrm{g} / \mathrm{mL}$ annexin $\mathrm{V}$-FITC (R\&D Systems Inc., Abingdon, United Kingdom) and $2.5 \mu \mathrm{g} / \mathrm{mL}$ propidium iodide (Sigma Chemical Co.) in calcium-containing binding buffer (HEPES with 0.25 $\mathrm{mM} \mathrm{CaCl}_{2}$ ). DNA flow cytometry was performed according to Nicoletti et al. (24). In brief, cells were resuspended in hypotonic fluorochrome solution containing $50 \mu \mathrm{g} / \mathrm{mL}$ propidium iodide (Sigma Chemical
Co.), $0.1 \%$ sodium citrate (Fluka Chemie AG, Buchs, Switzerland), and 0.1\% (vol/vol) Triton-X 100 (Fluka Chemie AG), and then incubated at $4{ }^{\circ} \mathrm{C}$ for 6 hours.

$R$ Nase protection assay. Third-passage primary human KCs were treated with FasR mAb, recombinant human IFN- $\gamma$, and supernatant from stimulated CD45RO ${ }^{+} \mathrm{T}$ cells diluted $50 \%$. The KCs were lysed on the plate, and the RNA was isolated according to the RNeasy protocol (QIAGEN AG, Basel, Switzerland), which includes DNase digestion. The RNase protection assay was performed according to the protocol of the manufacturer (PharMingen). Briefly, all RNA obtained from $3 \times 10^{6}$ cells $(3-4 \mu \mathrm{g})$ was hybridized overnight to the ${ }^{32} \mathrm{P}$-labeled RNA probe (hApo3c; PharMingen). Single-stranded RNA and free probe were digested by RNase A and RNase T1. Protected RNA was phenolized and precipitated, and then analyzed on a $6 \%$ denaturing polyacrylamide gel. Bands were visualized with phosphorous imaging (raytest; Schweiz AG, Urdorf, Switzerland).

Quantification of cytokines. IL-4, IL-5, IL-13, and IFN- $\gamma$ were determined by sandwich ELISA as described $(9,10)$. The sensitivity of IL-4 ELISA was at or below $20 \mathrm{pg} / \mathrm{mL}$ (mAb and IL-4 standard were provided by C.H. Heusser, Novartis Pharmaceuticals). The detection limit of the IL5 ELISA was $50 \mathrm{pg} / \mathrm{mL}$ (mAb and IL-5 standard were from PharMingen). The detection limit of IL-13 ELISA was $100 \mathrm{pg} / \mathrm{mL}$ (mAb and IL-13 standard were from PharMingen). The sensitivity of the IFN- $\gamma$ ELISA was at or below $10 \mathrm{pg} / \mathrm{mL}$ (mAb and IFN- $\gamma$ standard were gifts from S.S. Alkan, Novartis Pharmaceuticals). Soluble FasL was detected by a commercial ELISA kit (MBL Co., Nagoya, Japan) with a sensitivity of $0.1 \mathrm{ng} / \mathrm{mL}$.

Immunobistology. The tissue samples were placed in Tissue-Tek OCT compound (Sakura Finetek Europe BV, Zoeterwoude, The Netherlands) and stored at $-80^{\circ} \mathrm{C}$. Four-micrometer cryostat sections were prepared on gelatin-coated slides (Merck AG, Dietikon, Switzerland). After air drying, sections were fixed in acetone for 10 minutes at $4^{\circ} \mathrm{C}$. A three-step streptavidin-biotin complex peroxidase method (streptABComplex-peroxidase; DAKO A/S) was used. Briefly, sections were incubated with the primary mAb (CD4, CD8, and CD45R0 from DAKO A/S; FasL from Alexis Corp.; IFN- $\gamma$ receptor from Genzyme Pharmaceuticals; and FasR, anti-perforin, and anti-granzyme B from Ancell Corp., Bayport, Minnesota, USA) at $4^{\circ} \mathrm{C}$ overnight. This was followed by incubation with biotin-conjugated rabbit anti-mouse $\operatorname{IgG}$ and preformed streptABComplex-peroxidase (both from $\mathrm{DAKO} \mathrm{A} / \mathrm{S}$ ) at room temperature for 1 hour. Incubation with the peroxidase-specific substrate 3-amino-9ethylcarbazole (Sigma Chemical Co.) was used for visualization, with hematoxylin counterstaining. For control purposes, the primary mAb was replaced by an irrelevant isotype-matched $\mathrm{mAb}$ that consistently yielded negative results.

Nick-end labeling of DNA from apoptotic KCs. Apoptotic cells may be identified in situ by histochemical techniques with staining of double-stranded DNA breaks. 
Terminal deoxynucleotidyl transferase-mediated dUTP nick-end labeling (TUNEL) was performed as described (25). This technique is used widely, and has been found to be sensitive and to preferentially detect DNA breaks encountered in apoptosis. Briefly, TUNEL reaction mixture (Boehringer Mannheim GmbH, Mannheim, Germany) was added to the samples, which were incubated for 60 minutes at $37^{\circ} \mathrm{C}$. Incorporated fluorescein was detected by anti-fluorescein $\mathrm{Ab}$ Fab fragments from sheep, conjugated with alkaline phosphatase.

Identification of apoptosis by HOECHST staining. HOECHST staining was done according to Norris et al. (26) in KCs cultured in Transwell plates (CorningCostar Corp.) and in lesional skin sections. After fixation with $4 \%$ paraformaldehyde and $200 \mathrm{mM}$ dihydrogen phosphate ( $\mathrm{pH} 7.0$ ) overnight at $4^{\circ} \mathrm{C}$, staining was performed with HOECHST 33342 dye $(1 \mu \mathrm{g} / \mathrm{mL}$; Sigma Chemical Co.) for 5 minutes. Stained sections were evaluated with an ultraviolet microscope (Axiovert 405M; Carl Zeiss AG, Feldbach, Switzerland).

Cocultures of normal buman skin and skin equivalents with $T$ cells. Normal healthy human skin obtained during plastic surgery was cut into small pieces (approximately $6 \mathrm{~mm} \times 3 \mathrm{~mm}$ ). This skin was then placed in the upper compartment of Transwell plates, not allowing cell-cell contact, and was exposed for 3 days to heterol- ogous unstimulated and stimulated $\mathrm{CD} 45 \mathrm{RO}^{+} \mathrm{T}$ cells that were placed in the lower compartment $\left(10^{6} /\right.$ well). From normal, healthy human skin obtained during plastic surgery, a three-dimensional whole-skin model was built up from dermal fibroblasts embedded in a biomatrix and multilayered epidermis with stratum corneum, according to the method of the reconstructed skin equivalent AST-2000 (CellSystems Biotechnologie Vertrieb GmbH, St. Katharinen, Germany) (27). The cultured skin equivalents, grown for 2 weeks at the air-liquid interface, were then exposed together with their inserts (not allowing cell-cell contact) for 3 days to heterologous unstimulated and stimulated $\mathrm{CD}_{45 \mathrm{RO}^{+}}$ $\mathrm{T}$ cells. The skin pieces were then fixed in Bouin's solution (Sigma Chemical Co.) and were further processed for staining with hematoxylin/eosin and TUNEL.

Statistical analysis. Results are shown as mean \pm SD. The paired Student's $t$ test was used for comparison of paired conditions.

\section{Results}

KC injury induced by activated T cells. The histologic hallmark of eczematous disorders consists of a marked $\mathrm{KC}$ pathology. Acantholysis and spongiosis in the epidermis is characterized by impairment or loss of cohesion between KCs and an influx of fluid from the dermis,
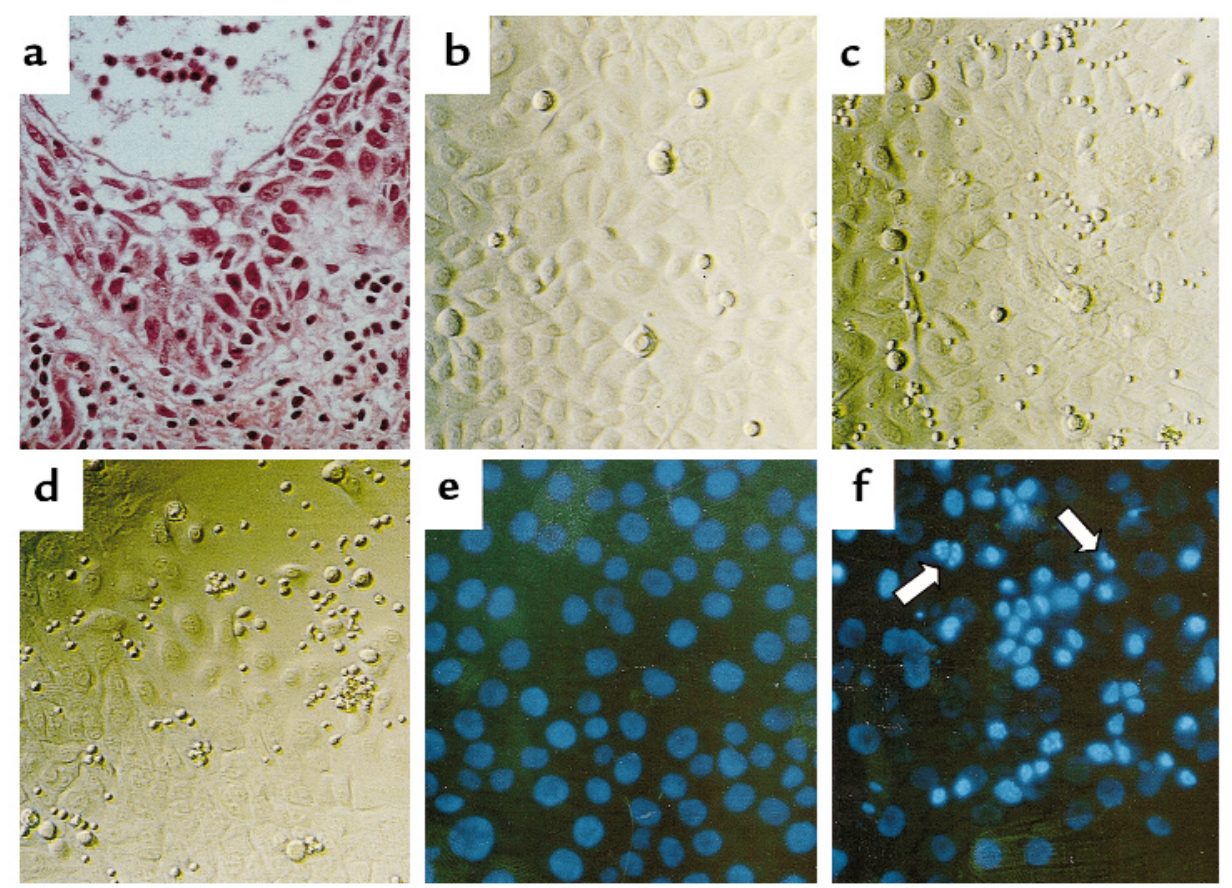

\section{Figure 1}

(a) Representative histologic findings of acute eczematous dermatitis. A dense subepidermal inflammatory infiltrate and marked epidermal acantholytic and spongiotic changes progress to vesicle formation. Hematoxylin/eosin staining. $\times 400$. (b-d) Signs of KC injury after coculture with autologous T cells. Photomicrographs from 96-well plates with an inverted microscope equipped with phase contrast. $\times 200$. (b) Intact monolayer of cultured third-passage primary human KCs. The KCs are relatively uniform in size and morphology. (c) Intact monolayer of KCs after 3 days in coculture with unstimulated autologous CD45RO+ T cells. (d) Partly destroyed monolayer of KCs after 3 days in coculture with autologous $C D 45 R^{+} T$ cells stimulated with anti-CD2, anti-CD3, and anti-CD28 mAb's. (e and $\mathbf{f}$ ) Induction of KC apoptosis in vitro. Identification of apoptotic nuclei with HOECHST staining. $\times 200$. (e) Intact monolayer of KCs after 3 days of coculture in Transwell plates with unstimulated $\mathrm{CD}^{2} 5 \mathrm{RO}^{+} \mathrm{T}$ cells. (f) Induction of KC apoptosis after coculture in Transwell plates with stimulated $\mathrm{CD} 45 \mathrm{RO}^{+} \mathrm{T}$ cells. Note bright, condensed nuclei and nuclear fragmentation (arrows), signs of KC apoptosis. 
a

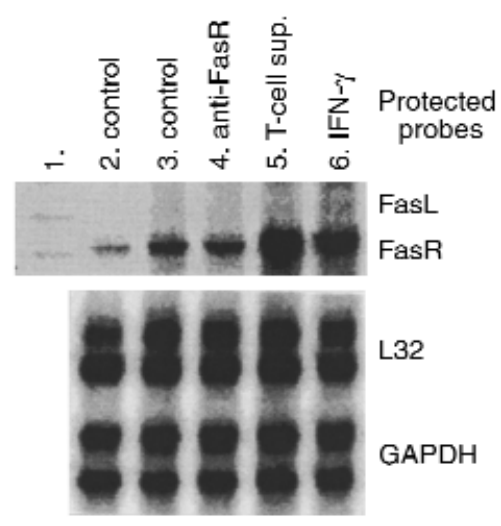

c

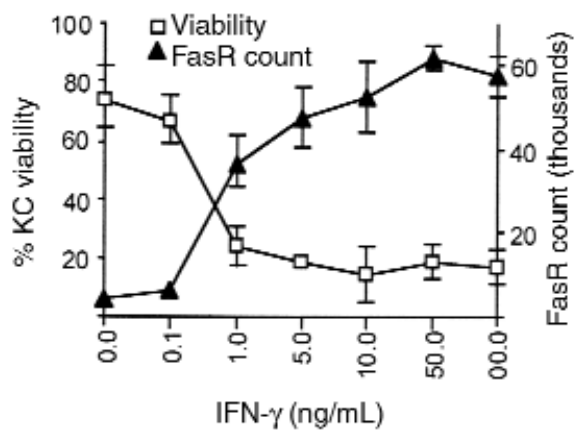

b

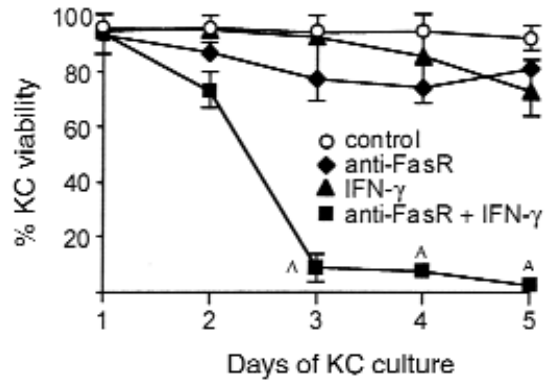

d

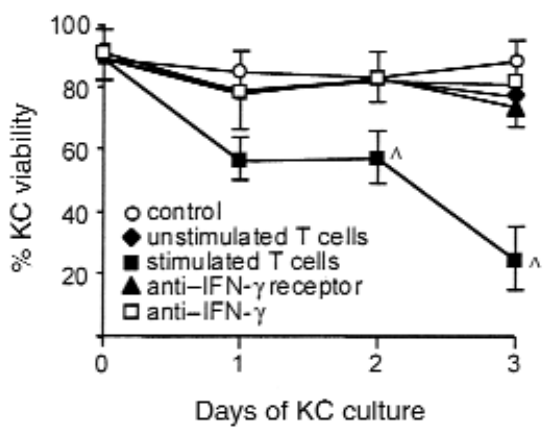

Figure 2

(a) Expression of FasR mRNA by primary human KCs. Lane 1: unprotected template. Lane 2: after 8 hours of KC culture. Lane 3: after 24 hours of KC culture. Lane 4: after 16 hours of KC culture followed by 8 hours with $1.0 \mu \mathrm{g} / \mathrm{mL}$ anti-FasR mAb. Lane 5 : after 16 hours of KC culture followed by 8 hours with diluted (50\%) supernatant (sup.) from stimulated CD45RO+ $T$ cells. Lane 6: after 16 hours of KC culture followed by 8 hours with $1.0 \mathrm{ng} / \mathrm{mL} \mathrm{IFN}-\gamma$. A representative result of three experiments is shown. (b) IFN- $\gamma$ and Fas-induced KC apoptosis. $\mathrm{KC}$ viability was monitored by ethidium bromide exclusion and flow cytometry. Treatments shown are control (KCs alone), $1 \mu \mathrm{g} / \mathrm{mL}$ activating anti-FasR $\mathrm{mAb}, 10 \mathrm{ng} / \mathrm{mL}$ IFN- $\gamma$, and $1 \mu \mathrm{g} / \mathrm{mL}$ anti-FasR mAb added 1 day after starting incubation with $10 \mathrm{ng} / \mathrm{mL}$ IFN- $\gamma$. ${ }^{A} P<0.05$. (c) IFN- $\gamma$-induced FasR counts exhibit a threshold for KC apoptosis. KCs were pretreated with the indicated doses of IFN- $\gamma$; $1 \mu \mathrm{g} / \mathrm{mL}$ antiFasR $\mathrm{mAb}$ was added 1 day after starting incubation with IFN- $\gamma$. KC viability was assessed by ethidium bromide exclusion and flow cytometry at day 3 . FasR count 1 day after starting incubation with indicated doses of IFN- $\gamma$. (d) $C D 45 R O^{+} T$ cell-induced KC death is inhibited by blocking IFN- $\gamma$. KC viability was monitored by ethidium bromide exclusion and flow cytometry. In the flow cytometry setting, KCs and T cells are gated according to forward and side scatter. Both cell populations were therefore monitored separately. Coculture of primary human $\mathrm{KCs}$ and autologous unstimulated or stimulated (with anti-CD2, anti-CD3, and anti-CD28 mAb) CD45RO ${ }^{+} \mathrm{T}$ cells. ${ }^{A} P<0.05$. Inhibition of $\mathrm{CD}_{45 \mathrm{RO}^{+}} \mathrm{T}$ cell-induced KC death by $1 \mu \mathrm{g} / \mathrm{mL}$ blocking anti-IFN- $\gamma$ receptor $\mathrm{mAb}$ and $20 \mu \mathrm{g} / \mathrm{mL}$ neutralizing anti-IFN- $\gamma \mathrm{mAb}$. Results in $\mathbf{b}-\mathbf{d}$ represent mean \pm SD of triplicate cultures from three different experiments. Control, KCs alone.

progressing to vesicle formation (Figure 1a and ref. 28). In preliminary experiments, we observed several morphologic changes in cultured primary human KCs (Figure $1 \mathrm{~b}$ ) in the coculture with autologous T cells. Resting, unstimulated $\mathrm{T}$ cells did not affect $\mathrm{KC}$ morphology (Figure 1c), whereas KCs cocultured with stimulated T cells were shrunken and rounded; they finally detached from the plates and died (Figure 1d). The type of KC death was investigated by demonstration of apoptotic features such as chromatin condensation and fragmented nuclei made visible by HOECHST staining (26). To eliminate the possibility that the apoptotic bodies were derived from $\mathrm{T}$ cells, $\mathrm{KCs}$ and $\mathrm{T}$ cells were separated in Transwell plates. As shown in Figure 1f, KC apoptosis was induced by soluble factors from stimulated $\mathrm{T}$ cells, whereas resting $\mathrm{T}$ cells did not show any effect (Figure 1e). These results demonstrated that KCs are target cells of activated $T$ cells that invade the epidermis in the efferent phase of eczematous disorders, suggesting that KC injury and death may have a decisive contribution to the $\mathrm{KC}$ pathology seen in eczema.

Role of IFN- $\gamma$ and FasR in KC apoptosis. We then focused on the mechanism of $\mathrm{KC}$ death induced by activated $\mathrm{T}$ cells. FasR (CD95) is a $47-\mathrm{kDa}$ membrane protein that transduces an apoptotic signal into the cell when triggered by its ligand (FasL) or by agonistic Abs $(29,30)$. KCs expressed detectable levels of FasR mRNA, which significantly increased after incubation with IFN- $\gamma$ or with supernatants from stimulated $\mathrm{CD}_{45 \mathrm{RO}^{+}}$(memory/effector) T cells (Figure 2a). In contrast, FasL mRNA was not detected in the KCs. As shown in Figure 2b, unstimulated KCs showing low FasR expression were resistant to Fas-mediated killing. IFN- $\gamma$, which is known to induce growth arrest and the expression of squamous 


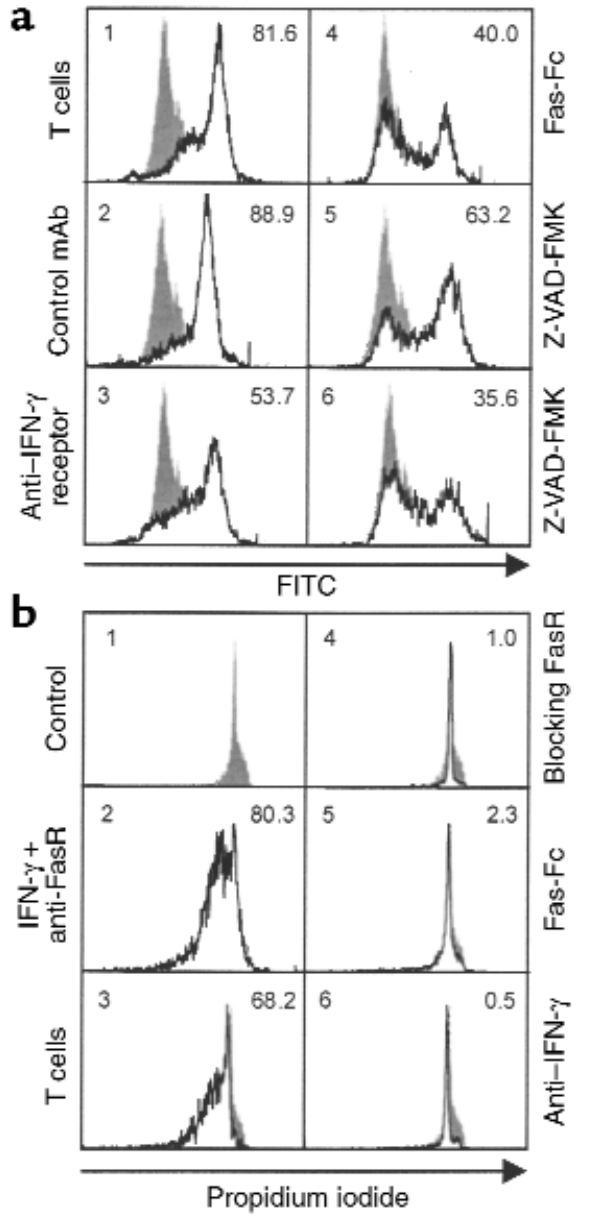

Figure 3

Induction and regulation of KC apoptosis in KC-T cell cocultures. (a) Coculture of primary human KCs and stimulated autologous $\mathrm{CD} 45 \mathrm{RO}^{+} \mathrm{T}$ cells. After 3 days of coculture, cells were stained with annexin $\mathrm{V}$ and subjected to flow cytometry. With the indicated stimuli, the number of apoptotic KCs increases and the cells show an increase in annexin $\mathrm{V}$ binding (open histograms). Filled histograms show live KCs. The percentage of apoptotic KCs is indicated at upper right. Panel 1: KC apoptosis induced by coculture with $\mathrm{CD}^{2} 5 \mathrm{RO}^{+} \mathrm{T}$ cells stimulated with anti-CD2, anti-CD3, and antiCD28 mAb's. Panel 2: Isotype control mAb. Panel 3: Blocking anti-IFN- $\gamma$ receptor $\mathrm{mAb}(1 \mu \mathrm{g} / \mathrm{mL})$. Panel 4 : Fas-Fc protein $(1$ $\mu \mathrm{g} / \mathrm{mL})$. Panel 5: The caspase inhibitor Z-VAD-FMK $(50 \mu \mathrm{M})$. Panel 6: Z-VAD-FMK $(100 \mu \mathrm{M})$. (b) Coculture of primary human KCs and stimulated autologous CD45RO $\mathrm{R}^{+} \mathrm{T}$ cells in Transwell plates. After 3 days in coculture, permeabilized KCs were stained with propidium iodide and subjected to flow cytometry. Filled histograms demonstrate control KCs containing diploid DNA. The percentage of apoptotic KCs with hypodiploid DNA (open histograms) is shown in the upper right corner. Panel 1: Primary human KCs alone were cultured in the lower well. Panel 2: KCs were pretreated with $10 \mathrm{ng} / \mathrm{mL}$ IFN$\gamma$ for 24 hours, and KC apoptosis was determined 3 days after 1 $\mu \mathrm{g} / \mathrm{mL}$ activating anti-FasR $\mathrm{mAb}$ was added. Panel 3: KC apoptosis induced by Transwell coculture with stimulated $\mathrm{CD} 45 \mathrm{RO}^{+} \mathrm{T}$ cells. Panel 4: Inhibition of KC apoptosis induced by IFN- $\gamma$ and anti-FasR $\mathrm{mAb}$, with $1 \mu \mathrm{g} / \mathrm{mL}$ ZB4 blocking mAb. Panels 5 and 6 : Inhibition of KC apoptosis induced by Transwell coculture with stimulated $\mathrm{CD}^{2} 5 \mathrm{RO}^{+} \mathrm{T}$ cells, with $1 \mu \mathrm{g} / \mathrm{mL}$ Fas-Fc protein (panel 5), and with $10 \mu \mathrm{g} / \mathrm{mL}$ neutralizing anti-IFN- $\gamma \mathrm{mAb}$ (panel 6 ). Results in $\mathbf{a}$ and $\mathbf{b}$ are representative of three experiments. differentiation genes (31), showed no significant killing activity. However, KCs pretreated with IFN- $\gamma$ (but not TNF- $\alpha$, IL-4, IL-5, IL-12, or IL-13; data not shown) were efficiently killed by cross-linking of FasR with anti-FasR $\mathrm{mAb}$ or soluble FasL (Figure $2 \mathrm{~b} ; P<0.05$ ). In $\mathrm{KCs}$, the sensitivity to Fas-induced death correlated very well with levels of cell-surface FasR (Figure 2c). Increasing doses of IFN- $\gamma$ induced FasR expression on KCs. When the number of FasR molecules on KCs reached a threshold of approximately 40,000 per KC, the cells became susceptible to apoptosis.

Induction and regulation of $K C$ apoptosis by $T$ cells. Skininfiltrating $\mathrm{T}$ cells belong primarily to the $\mathrm{CD}^{2} 5 \mathrm{RO}^{+}$ subset $(32,33)$. In KC-T cell cocultures, we observed killing of KCs by stimulated autologous $\mathrm{CD}^{2} 5 \mathrm{RO}^{+} \mathrm{T}$ cells (Figure $2 \mathrm{~d} ; P<0.05$ ). Ligation of the T-cell receptor-CD3 complex by antigen peptides or mAb's to Tcell receptor-CD3 triggers a series of activation events, eventually leading to cell proliferation and cytokine production $(34,35)$. It is known that antiCD3 mAb cross-linking induces the expression of cellsurface and soluble FasL by T cells (36). Accordingly, $\mathrm{KC}$ killing was significant only after activation of $\mathrm{T}$ cells, either with phorbol ester and calcium ionophore, cross-linking of the T-cell receptor-CD3 complex by plate-bound anti-CD3 (data not shown), or a combination of anti-CD2, anti-CD3, and antiCD28 mAb's (Figure 2d; $P<0.05$ ). Cytokine pretreatment of KCs was not necessary for death; however, it is apparent that sufficient IFN- $\gamma$ was produced by the stimulated T cells themselves to upregulate KC FasR expression. As seen in Figure 2d, KC killing could be inhibited by pretreatment with either neutralizing anti-IFN- $\gamma$ mAb or by the IFN- $\gamma$ receptor-blocking mAb. Neutralizing mAb's against IL-4, IL-5, and IL13 , and the mutant IL-4 antagonist showed no inhibitory activity (data not shown). We further examined whether FasR engagement on IFN- $\gamma$-treated KCs triggered apoptotic cell death. Stimulated T cells induced $\mathrm{KC}$ apoptosis as demonstrated by HOECHST staining (Figure 1f), by annexin $\mathrm{V}$ staining of membrane phosphatidylserine inversion in $\mathrm{KC}-\mathrm{T}$ cell cocultures (Figure 3a), and by DNA fragmentation in Transwell cocultures with no cell-cell contact allowed (Figure 3b). This demonstrates that soluble FasL released from $\mathrm{T}$ cells induces apoptosis in $\mathrm{KCs}$ in the absence of cell-cell contact. KC apoptosis was again inhibited by neutralizing IFN- $\gamma$, blocking the IFN- $\gamma$ receptor, and by pretreatment of KCs with the caspase inhibitor Z-VAD-FMK (37). To further test that FasR expression on KCs is triggered by FasL from stimulated $\mathrm{T}$ cells, we used the human Fas-Fc protein as a competitive inhibitor of FasL-FasR interactions (38). We found that the Fas-Fc protein effectively inhibited apoptosis of KCs induced by stimulated T cells (Figure 3 , $a$ and $b$ ).

Induction of KC apoptosis by type 1 and type $2 \mathrm{~T}$ cells. To establish a more disease-related model for KC apoptosis in eczematous disorders, we investigated the effects 
of different phenotypes of stimulated T cells on KCs. Type $1 \mathrm{CD} 4^{+}$and $\mathrm{CD} 8^{+} \mathrm{T}$ cells contain and secrete primarily the cytokine IFN- $\gamma$, and only low amounts of IL- 4 and IL-5. In contrast, type $2 \mathrm{CD}^{+}$and $\mathrm{CD}^{+} \mathrm{T}$ cells contain and secrete IL-4, IL-5, and IL-13, but only low amounts of IFN- $\gamma(39)$. The type $1 \mathrm{CD}^{+}$and $\mathrm{CD} 8^{+}$ $\mathrm{T}$ cells were able to induce $\mathrm{KC}$ death (Figure 4a; $P<0.05)$. In contrast, type $2 \mathrm{~T}$ cells had no effect on KCs after differentiation. Additionally, we combined type 1 and type $2 \mathrm{~T}$ cells and measured KC apoptosis. This mixture induced apoptosis less than type 1 cells alone did, but apoptosis was still highly significant (data not shown). IL-12 is produced mainly by macrophages and dendritic cells, and promotes type 1 $\mathrm{T}$-cell responses by selective upregulation of IFN- $\gamma$ production by T cells (40). Stimulation of type $2 \mathrm{CD}^{+}$or $\mathrm{CD}^{+} \mathrm{T}$ cells with IL-12 increased IFN- $\gamma$ production and ablated IL-4 production (Figure $4 \mathrm{~b} ; P<0.05$ ). In this case, IL-12 stimulation of type $2 \mathrm{~T}$ cells enabled the induction of $\mathrm{KC}$ apoptosis (Figure 4c; $P<0.05$ ). Supernatants from stimulated type 1 and type $2 \mathrm{~T}$ cells released soluble FasL; addition of IL-12 did not influence the secretion of soluble FasL (Figure 4d).
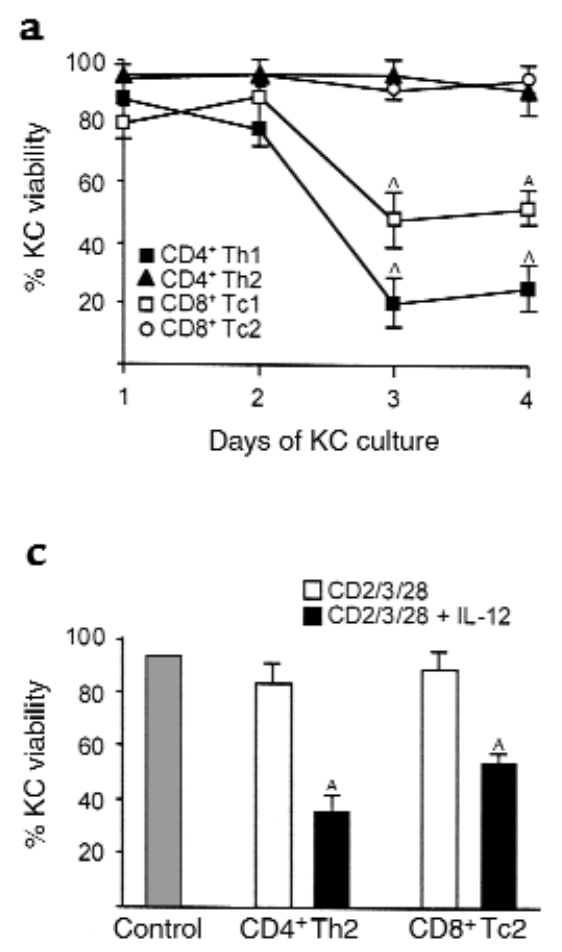

Features of inflammation in eczematous dermatitis. The histologic appearance of acute lesional $\mathrm{AD}$ and $\mathrm{ACD}$ skin was defined by various degrees of dermal perivascular infiltration with mononuclear cells, mostly consisting of $\mathrm{CD}^{+} \mathrm{T}$ cells as well as $\mathrm{CD} 8^{+} \mathrm{T}$ cells (Figure 5 , $\mathrm{a}-\mathrm{c})$. The expression of CD45RO on the $\mathrm{T}$ cells suggests a previous encounter with antigens; many of the T cells showed signs of intralesional activation as defined by membrane expression of HLA-DR (2). It should be noted here that $\mathrm{T}$ cells constitute the major cells in dermal infiltrates, and that some of the $\mathrm{CD}^{+}$and $\mathrm{CD}^{+} \mathrm{T}$ cells invade the epidermis (Figure 5, b and c). Therefore, membrane-bound FasL on T cells can trigger FasR on KCs by cell-cell contact. Figure 5d demonstrates FasL immunoreactivity on lesional $\mathrm{T}$ cells of acute $\mathrm{AD}$. The basal and suprabasal compartment of the epidermis was strongly reactive for FasR, and the KCs showed high FasR surface expression in acute AD (Figure 5e). Similarly, ACD skin showed FasL expression on T cells and FasR expression on KCs (data not shown). Chronic AD lesions displayed weaker FasR immunoreactivity in basal KCs. Healthy control skin displayed no inflammatory infiltrate and no KC staining with anti-FasR b

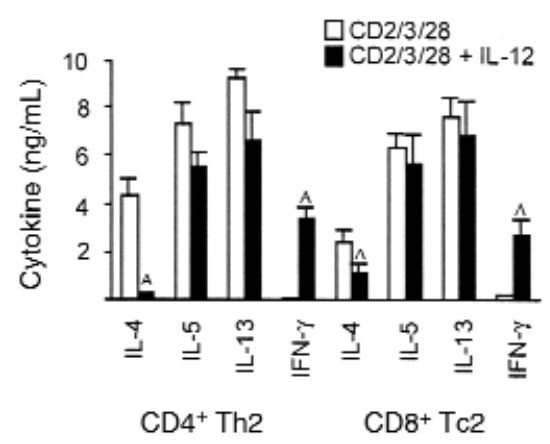

d

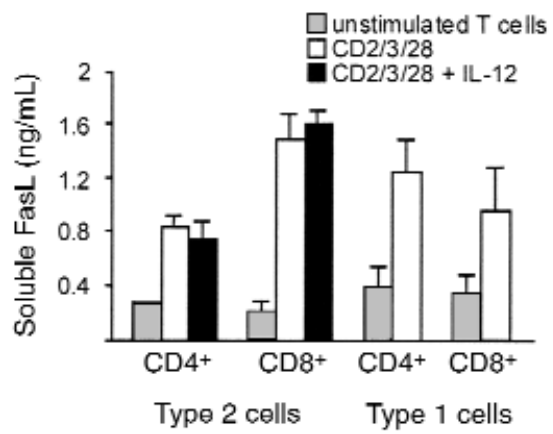

Figure 4

Induction of KC apoptosis by type 1 and type $2 \mathrm{~T}$ cells. (a) Type 1 but not type $2 \mathrm{~T}$ cells mediated KC death. Coculture of primary human KCs and heterologous differentiated type 1 and type $2 \mathrm{~T}$ cells. ${ }^{A} P<0.05$. (b) Cytokine content of differentiated and stimulated type $2 \mathrm{~T}$ cells as determined by ELISA. CD4 ${ }^{+}$T helper 2 (Th2) and CD8 ${ }^{+} T$ cytotoxic 2 (Tc2) cells were stimulated with anti-CD2, anti-CD3, and anti-CD28 mAb's or with a combination of anti-CD2, anti-CD3, and anti-CD28 mAb's and IL-12. ${ }^{A} P<0.05$. (c) Coculture of primary human KCs and heterologous differentiated type $2 \mathrm{~T}$ cells. KC viability was measured by ethidium bromide exclusion and flow cytometry at day 3 . Control, KCs alone. CD4 ${ }^{+}$ Th2 cells and CD8 ${ }^{+}$Tc2 cells were stimulated with anti-CD2, anti-CD3, and anti-CD28 mAb's or with a combination of anti-CD2, anti-CD3, and anti-CD28 mAb's and IL-12. ${ }^{A} P<0.05$. (d) Levels of soluble FasL in T-cell supernatants as determined by ELISA. CD4 ${ }^{+}$Th1/Th2 and CD8 ${ }^{+}$ $\mathrm{Tc} 1 / \mathrm{Tc} 2$ cells were stimulated with anti-CD2, anti-CD3, and anti-CD28 mAb's or with a combination of anti-CD2, anti-CD3, and anti-CD28 mAb's and IL-12. Results shown represent three $(\mathbf{a}, \mathbf{c})$ to five $(\mathbf{b}, \mathbf{d})$ experiments and are shown as mean \pm SD from triplicate cultures. 

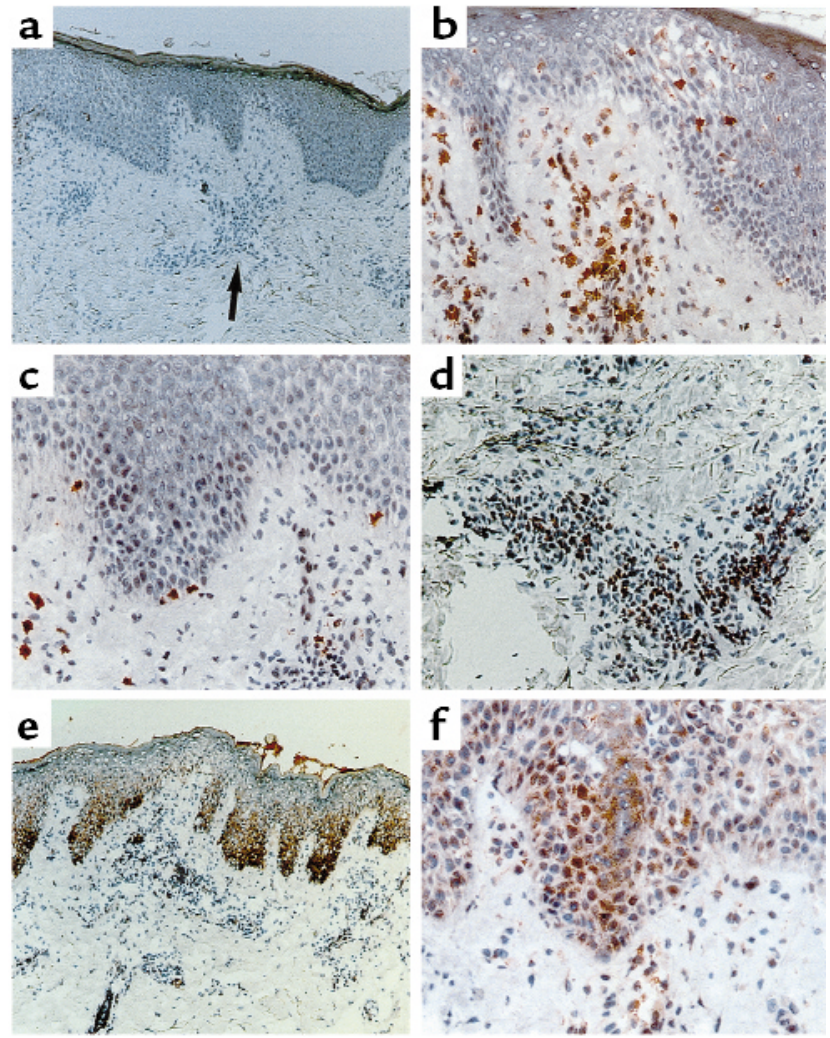

Figure 5

Features of inflammation in AD. Immunohistologic staining with 3amino-9-ethylcarbazole substrate and counterstaining with hematoxylin. (a) Subepidermal inflammatory infiltrate, consisting mainly of lymphocytes. $\times 100$. (b) CD4 ${ }^{+}$cells infiltrating the spongiotic epidermis. $\times 200$. (c) $\mathrm{CD}^{+}$cells. $\times 200$. (d) $\mathrm{FasL}^{+}$cells in the dermal cellular infiltrate. $\times 200$. (e) Strong immunoreactivity of FasR in the basal epidermis; weaker staining in the T-cell infiltrate. $\times 100$. (f) Detection of IFN- $\gamma$ receptor on KCs and infiltrating T cells. $\times 200$

$\mathrm{mAb}$. KCs from healthy individuals and from $\mathrm{AD}$ and ACD patients expressed IFN- $\gamma$ receptors on their surface in vitro and in vivo (Figure $5 \mathrm{f}$ and ref. 41 ).

Demonstration of $K C$ apoptosis in $A D$, atopy patch tests, $A C D$, and cultures of healthy buman skin and skin equivalents. Skin biopsies from acute $\mathrm{AD}$, chronic $\mathrm{AD}$, atopy patch tests, and acute ACD were analyzed using the TUNEL technique (Figure 6, a and b) and HOECHST staining (Figure 6, c and d). Patch-test reactions to aeroallergens constitute a suitable model for the study of allergic inflammation in $\mathrm{AD}$. They are specific for sensitized $\mathrm{AD}$ patients, and do not occur in healthy volunteers or in patients suffering from asthma or rhinitis (42). As a negative control, we used normal skin from healthy individuals. No TUNEL-stained cells were observed in the stratum basale or stratum spinosum of normal skin. TUNEL-stained nuclei were rarely seen in the lumen of spongiotic vesicles of acute $\mathrm{AD}$ and $\mathrm{ACD}$. As shown in Figure 6, $\mathrm{a}$ and $\mathrm{b}$, TUNEL-stained KCs are visible primarily in the cohesive epidermis (stratum spinosum) of acute lesions in which acantholysis and spongiosis had not progressed to vesicle formation. In chronic AD,
TUNEL-stained KCs are visible at a lower frequency than in acute $\mathrm{AD}$ and ACD. HOECHST staining was used as a second method, complementing TUNEL staining $(26,43)$. In Figure 6, c and d, condensed and fragmented nuclei of apoptotic cells are demonstrated in acute $\mathrm{AD}$ and $\mathrm{ACD}$ lesions. Besides the demonstration of $\mathrm{KC}$ apoptosis in acute $\mathrm{AD}$, chronic $\mathrm{AD}$, atopy patch tests, and acute ACD, we also investigated apoptosis in cocultures of normal human skin of healthy individuals with stimulated T cells, and in cocultures of skin equivalents with stimulated T cells. We were able to demonstrate the induction of $\mathrm{KC}$ apoptosis by in vitro exposure of normal human skin (Figure 6e) and cultured skin equivalents (Figure 6, $\mathrm{f}$ and $\mathrm{g}$ ) to stimulated $\mathrm{CD}^{2} 5 \mathrm{RO}^{+} \mathrm{T}$ cells in Transwell cocultures. In contrast, unstimulated $\mathrm{CD} 45 \mathrm{RO}^{+} \mathrm{T}$ cells had no effect.

\section{Discussion}

This study demonstrates that Fas-induced KC apoptosis caused by skin-infiltrating $\mathrm{T}$ cells is a major mechanism in the pathogenesis of eczematous dermatitis. In recent years, much interest has focused on apoptosis as a mechanism to control cell numbers (44). The interactions between FasL and FasR are important in maintaining lymphoid cell numbers. However, it is likely that FasL-FasR interaction also plays a role in other important biologic processes. Various cells in the body constitutively express FasR, or can be induced to do so $(45,46)$. KCs express FasR $(47$, 48 ), and the sensitivity to Fas-induced KC death correlated very well with numbers of cell surface FasR in our study. An explanation for this may be that quantitative increases in FasR expression above a certain threshold level result in a signaling intensity that promotes apoptosis. On the other hand, it is possible that the signal transduction pathway for Fas-induced apoptosis is functionally inactive in unstimulated KCs. The threshold for IFN- $\gamma$ in the induction of FasR on KCs appears to be in the range of $0.1-1.0 \mathrm{ng} / \mathrm{mL}$.

FasL expression is usually limited to activated $T$ cells, natural killer cells, and cells of certain immunologically privileged sites (49). T cells appear to be important players regulating inflammatory processes in eczematous dermatitis (6-18). This is supported by the observation that immunosuppressive drugs such as FK-506 and glucocorticoids, which block T-cell activation, are effective in treatment of eczematous disorders $(4,5)$. The coupling of Fas signaling to the death pathway involves receptor trimerization followed by the binding of adapter proteins and then the caspase enzyme cascade, ultimately resulting in apoptosis $(29,30)$. Our studies using the caspase inhibitor Z-VAD-FMK (37) show that caspase activation is also critical for Fas-mediated apoptosis of KCs. In addition, recombinant Fas-Fc protein (38) prevents $\mathrm{T}$ cell-mediated KC apoptosis. This protective effect indicates that the FasL-FasR interaction is responsible for $\mathrm{T}$ cell-mediated $\mathrm{KC}$ apoptosis. The lethal hit is delivered to KCs by FasL expressed on the surface of $\mathrm{T}$ cells that invade the epidermis, and 

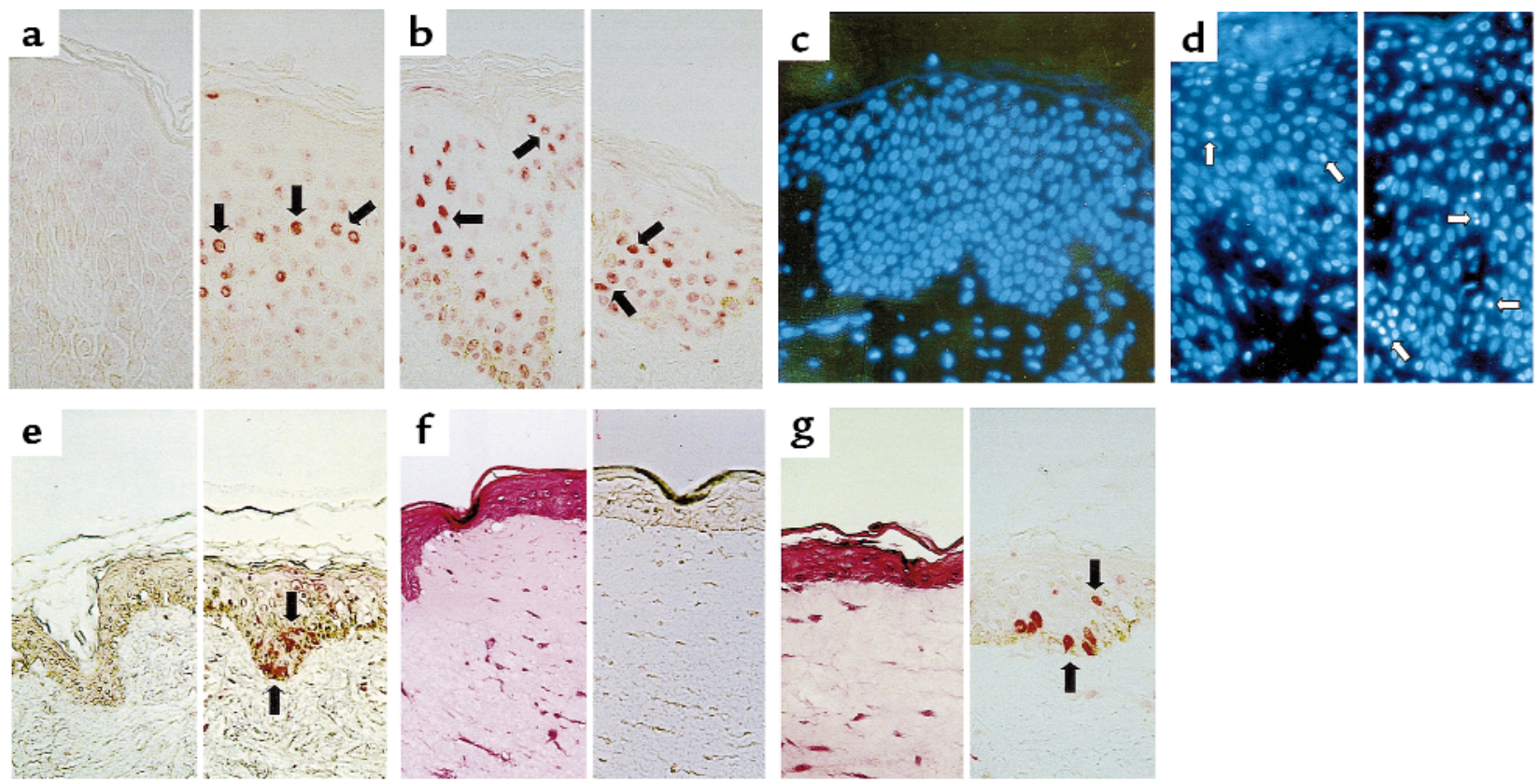

\section{Figure 6}

Demonstration of apoptotic KCs in $A D$, atopy patch tests, $A C D$, and in vitro induced eczematous dermatitis. Skin sections were subjected to TUNEL (a, b, $\mathbf{e}-\mathbf{g})$ or HOECHST staining (c, d) without counterstaining. (a) Healthy normal skin as a negative control (left); lesional skin of acute AD (right). Red condensed and partly fragmented nuclei indicate positive staining of apoptotic KCs (some of these are indicated by arrows). $\times 400$. (b) Left: Acute ACD; 2+ patch test 48 hours after exposure to $5 \%$ nickel sulfate. Right: 2+ atopy patch test 72 hours after exposure to 10,000 protein nitrogen units of house dust mite. $\times 400$. (c) Normal, healthy skin as a negative control. $\times 200$. (d) Left: Lesional skin of acute AD. Right: Acute ACD. 2+ patch test 48 hours after exposure to $5 \%$ nickel sulfate. Apoptotic cells show condensed or fragmented nuclei (some of these are indicated by arrows). $\times 400$. (e) Normal human skin after 3 days of in vitro culture with unstimulated CD45RO ${ }^{+} \mathrm{T}$ cells. Left: No TUNEL-stained KCs are detectable. Right: Normal human skin after 3 days of in vitro culture exposed to stimulated CD45RO ${ }^{+}$ T cells. Features of spongiosis and numerous apoptotic KCs are detectable (arrows). $\times 200$. (f) Cultured skin equivalent after 3 weeks of in vitro culture. Left: KC layers and the stratum corneum are visible (hematoxylin/eosin staining). Right: TUNEL staining. No TUNEL-stained nuclei are detectable. $\times 400$. (g) Cultured skin equivalent after 3 days exposed to stimulated $C D 45 R O^{+} T$ cells. There are signs of KC damage (left). With the TUNEL technique, several apoptotic nuclei are stained in the basal and suprabasal epidermis (arrows, right). Results shown in $\mathbf{e}-\mathbf{g}$ are representative of two experiments with healthy skin and three experiments with cultured skin equivalents.

probably by soluble FasL released from T cells. IFN- $\gamma$, which increases FasR expression on KCs, is a further prerequisite in T cell-mediated $\mathrm{KC}$ apoptosis. This is demonstrated by the fact that blocking of IFN- $\gamma$ totally abrogates $\mathrm{KC}$ apoptosis induced by activated $\mathrm{T}$ cells. Partial contributions by other cytokines and apoptotic mechanisms were principally eliminated in experiments demonstrating neutralization of the effects by blocking IFN- $\gamma$ and by using Fas-pathway antagonists. It has been proposed that the basal epidermis is resistant to apoptosis due to highly developed antiapoptotic defenses, which are reversible and decrease during differentiation (26). Adding IFN- $\gamma$ causes cultured KCs to differentiate and lose resistance to apoptosis (31). Thus the increased susceptibility to killing by Fas ligation in vitro may be due to both increased FasR expression and reduced anti-apoptotic defenses.

Eczematous skin lesions with distinct etiology are associated with T-cell infiltration in the epidermis, contact between $\mathrm{T}$ cells and KCs, and a marked KC pathology $(28,50,51)$. KCs in inflamed skin express HLA-DR and ICAM-1, which are not expressed on KCs of normal skin $(1,2)$. The only mediator known to date that induces HLA-DR on KCs is IFN- $\gamma$. Together, these data suggest a model of $\mathrm{T}$ cell-induced $\mathrm{KC}$ apoptosis in the pathogenesis of eczematous dermatitis. In an early step, $\mathrm{T}$ cells infiltrating the epidermis attach to KCs. Subsequently, the apoptosis signal is delivered to KCs by FasL expressed on the surface of $\mathrm{T}$ cells. In our experiments, FasL was detected only on the T-cell surface - not on $\mathrm{KCs}$ in $\mathrm{AD}, \mathrm{ACD}$, and patch-test lesions. However, in a study of toxic epidermal necrolysis, FasL expression on highly activated KCs was shown (52). In addition to FasL-FasR interaction, it is possible that activated $\mathrm{T}$ cells in eczematous dermatitis use granule-mediated killing by perforin and granzymes (53-55). However, granule-mediated cytotoxicity is not blocked by soluble Fas-Fc protein. Additionally, using immunohistology, we could not detect perforin or granzyme $B$ in lesional skin of $A C D$ and $A D$ patients.

To establish a more disease-related model for KC apoptosis in eczematous dermatitis, we investigated the effects of different subsets of activated $T$ cells on KCs. We demonstrated Fas-mediated apoptosis by both $\mathrm{CD}^{+}$and $\mathrm{CD} 8^{+}$type $1 \mathrm{~T}$ cells. There is accumulating evidence that not only $\mathrm{CD}^{+}$, but also $\mathrm{CD}^{+} \mathrm{T}$ 
cells possess the potential to both stimulate IgE production and promote allergic inflammation $(10,56)$. ACD is regarded as a type $1 \mathrm{~T}$ cell-mediated phenomenon in vivo, based on a number of observations (6, 7). Several results suggest that type 1 and type 2 cytokines secreted from activated $\mathrm{T}$ cells are important for the pathogenesis of AD (17). Clinical and histologic features of $\mathrm{AD}$ are almost indistinguishable from those present in ACD. Recent studies found IFN- $\gamma$ mRNA and protein highly expressed in eczematous skin of the vast majority of AD patients (15). IL12 stimulation of type $2 \mathrm{~T}$ cells abolished IL-4 and induced IFN- $\gamma$ production without major changes in IL-5 and IL-13 production. This explains the biphasic nature of the cytokine response observed in acute versus chronic $\mathrm{AD}$ lesions. Acute lesions and early response after epidermal allergen application were characterized with a predominant type 2 cytokine pattern $(4,16,57)$. Increased levels of IL-12 mRNA was demonstrated in chronic AD lesions (58), and chronic lesions were characterized by increased IFN $-\gamma$ and decreased IL-4 levels, with more or less constant IL-5 and IL-13 levels $(13,15,16,57,58)$. We observed killing of KCs by type $2 \mathrm{~T}$ cells after stimulation in the presence of IL-12. A cause-and-effect relationship between IL-12 and IFN- $\gamma$ expression may play a role in the conversion of type $2 \mathrm{~T}$ cells into IFN- $\gamma$-producing $\mathrm{T}$ cells that induce $\mathrm{KC}$ apoptosis in $\mathrm{AD}(15-17,58)$. In addition, virus infections and bacterial superantigens of AD skin may lead to IFN- $\gamma$ secretion of skin-infiltrating $\mathrm{T}$ cells $(14,58,59)$. Furthermore, KCs exhibited a relatively low threshold for FasR expression in response to IFN- $\gamma$, in the range of $0.1-1.0 \mathrm{ng} / \mathrm{mL}$.

Our results suggest that KC apoptosis is the initiating event in the development of the epidermal pathology seen in eczematous dermatitis. TUNEL and HOECHST staining showed that apoptotic KCs were present in the epidermis of patients with eczematous disorders. Most notably, KC apoptosis occurs in suprabasal cells, where spongiosis and acantholysis takes place. The basal layers of lesional epidermis had high levels of FasR, but it is likely that anti-apoptotic mechanisms prevent apoptosis of basal KCs (26). Apoptosis of individual KCs is the first event leading to disruption of epidermal continuity and vesicle formation. Damage to KCs leads to the loss of intercellular cohesion (acantholysis) and subsequent cleft formation. Fluid influx from the dermis and intercellular edema contributes to spongiosis, which is defined as widening of the intercellular space and a spongelike appearance of the epidermis (28). Based on our findings, the reason that not all the suprabasal KCs that express FasR undergo apoptosis uniformly in situ has to do with the activation of KCs induced by IFN- $\gamma$ and the ligation of FasR on the KCs by FasL expressed on T cells infiltrating the epidermis. Apoptosis of epidermal KCs is known to be an important feature in lichenoid tissue reaction, fixed drug eruption, graft-versus-host reaction, and the effects of ultraviolet radiation $(26,60,61)$.
Skin equivalents formed by KCs obtained from healthy skin and individuals with no skin disorders that are cocultured with fibroblasts embedded in collagen lattices represent promising tools for studies of skin pathology (27, 62). In cultured skin equivalents, KC differentiation and composition of the basement membrane are not exactly the same as in living epidermis. Therefore it is likely that the pro- and anti-apoptotic mechanisms operating in KCs are somewhat different in vivo, and basal KCs are probably more sensitive to apoptosis in skin equivalents. We also used the shortterm culture of normal human skin in a medium maintaining $\mathrm{KC}$ viability to investigate the effects of activated $\mathrm{T}$ cells on epidermal KCs. The induction of KC apoptosis in normal human skin and cultured skin equivalents after exposure to activated T cells establishes the in vivo relevance of $\mathrm{T}$ cell-mediated, Fas-induced $\mathrm{KC}$ apoptosis. The knowledge of this molecular basis is pivotal in understanding the development of pathology in eczematous disorders, and opens a future for more focused therapeutic applications.

\section{Acknowledgments}

This work was supported by grants from the Deutsche Forschungsgemeinschaft (TR460/1-1), the Swiss National Foundation (31.50590.97/1), and the Baumgarten Foundation (Zürich). We thank A. Speiser (Landspital Davos), J. Kammerer (Department of Pathology, Rätisches Kantonsspital Chur), R. Gillitzer, W. Dummer, A. Toksoy, H. Krenig, and C. Siedel (Department of Dermatology, University of Würzburg) for their work.

1. Singer, K.H., Tuck, D.T., Sampson, H.A., and Hall, R.P. 1989. Epidermal keratinocytes express the adhesion molecule intracellular adhesion molecule-1 in inflammatory dermatoses. J. Invest. Dermatol. 92:746-750.

2. Bieber, T., Dannenberg, B., Ring, J., and Braun-Falco, O. 1989. Keratinocytes in lesional skin of atopic eczema bear HLA-DR, CD1a and IgE molecules. Clin. Exp. Dermatol. 14:35-39.

3. Dustin, M.L., Singer, K.H., Tuck, D.T., and Springer, T.H. 1988. Adhesion of T lymphoblasts to epidermal keratinocytes is regulated by interferon- $\gamma$ and is mediated by intercellular adhesion molecule- 1 (ICAM-1). J. Exp. Med. 167:1323-1340.

4. Leung, D.Y. 1999. Pathogenesis of atopic dermatitis. J. Allergy Clin. Immunol. 104(Suppl.):S99-S108.

5. Rudikoff, D., and Lebwohl, M. 1998. Atopic dermatitis. Lancet. 351:1715-1721.

6. Grabbe, S., and Schwarz, T. 1998. Immunoregulatory mechanisms involved in elicitation of allergic contact hypersensitivity. Immunol. Today. 19:37-44.

7. Fong, T.A., and Mosman, T.R. 1989. The role of IFN- $\gamma$ in delayed-type hypersensitivity mediated by Th1 clones. J. Immunol. 143:2887-2893.

8. Santamaria Babi, L.F., et al. 1995. Circulating allergen-reactive T cells from patients with atopic dermatitis and allergic contact dermatitis express the skin-selective homing receptor, the cutaneous lymphocyteassociated antigen. J. Exp. Med. 181:1935-1940.

9. Akdis, M., Akdis, C.A., Weigl, L., Disch, R., and Blaser, K. 1997. Skinhoming $\mathrm{CLA}^{+}$memory $\mathrm{T}$ cells are activated in atopic dermatitis and regulate IgE by an IL-13 dominated cytokine pattern: IgG4 counter-regulation by CLA- memory T cells. J. Immunol. 159:4611-4619.

10. Akdis, M., et al. 1999. Skin-homing (cutaneous-lymphocyte-associatedantigen positive) $\mathrm{CD}^{+} \mathrm{T}$ cells respond to superantigen and contribute to eosinophilia and IgE production in atopic dermatitis. J. Immunol. 163:466-475.

11. Leung, D.Y. 1993. Role of IgE in atopic dermatitis. Curr. Opin. Immunol. 5:956-962.

12. Jujo, K., Renz, H., Abe, J., Gelfand, E.W., and Leung, D.Y. 1992. Decreased IFN- $\gamma$ and increased IL-4 production in atopic dermatitis promotes IgE synthesis. J. Allergy Clin. Immunol. 90:323-331.

13. Akdis, C.A., et al. 1999. T cells and T cell-derived cytokines as patho- 
genetic factors in the nonallergic form of atopic dermatitis. J. Invest. Dermatol. 113:628-634.

14. Herz, U., Bunikowski, R., and Renz, H. 1998. Role of T cells in atopic dermatitis. Int. Arch. Allergy Immunol. 115:179-190.

15. Grewe, M., Gyufko, K., Schöpf, E., and Krutman, J. 1994. Lesional expression of interferon- $\gamma$ in atopic eczema. Lancet. 343:25-26.

16. Thepen, T., et al. 1996. Biphasic response against aeroallergen in atopic dermatitis showing a switch from an initial Th2 response to a Th1 response in situ: an immunocytochemical study. J. Allergy Clin. Immunol. 97:828-837.

17. Grewe, M., et al. 1998. A role for Th1 and Th2 cells in the immunopathogenesis of atopic dermatitis. Immunol. Today. 19:359-361.

18. Spergel, J.M., Mizoguchi, E., Oettgen, H., Bhan, A.K., and Geha, R.S. 1999. Roles of Th1 and Th2 cytokines in a murine model of allergic dermatitis. J. Clin. Invest. 103:1103-1111.

19. Barker, J.N.W.N., Allen, M.H., and MacDonald, D.M. 1990. Alterations induced in normal human skin by in vivo interferon- $\gamma$. Br. J. Dermatol. 122:451-458.

20. Carroll, J.M., Crompton, T., Seery, J.P., and Watt, F.M. 1997. Transgenic mice expressing IFN- $\gamma$ in the epidermis have eczema, hair hypopigmentation and hair loss. J. Invest. Dermatol. 108:412-422.

21. Hanifin, J.M. 1982. Atopic dermatitis. J. Am. Acad. Dermatol. 6:1-13.

22. Viola, A., and Lanzavecchia, A. 1996. T cell activation determined by T cell receptor number and tunable thresholds. Science. 272:104-106.

23. Vermes, I., Haanen, C., Steffens-Nakken, H., and Reutlingsberger, C.D.M. 1995. A novel assay for apoptosis: flow cytometric detection of phosphatidylserine expression on early apoptotic cells using fluorescein labeled Annexin V. J. Immunol. Methods. 184:39-51.

24. Nicoletti, I., Migliorati, G., Pagliacci, M.C., Grignani, F., and Riccardi, C. 1991. A rapid and simple method for measuring thymocyte apoptosis by propidium iodide staining and flow cytometry. J. Immunol. Methods. 139:271-279.

25. Gavrieli, Y., Sherman, Y., and BenSasson, S.A. 1992. Identification of programmed cell death by in situ specific labeling of nuclear DNA fragmentation. J. Cell Biol. 119:493-501.

26. Norris, D.A., et al. 1997. Human keratinocytes maintain reversible antiapoptotic defenses in vivo and in vitro. Apoptosis. 2:136-148.

27. Noll, M., et al. 1999. Reconstructed human skin (AST-2000) as a tool for pharmaco-toxicology. Alternatives to Laboratory Animals. 27:302a. (Abstr.)

28. Wolff, K., Kibbi, A.G., and Mihm, M.C. 1993. Basic pathologic reactions of the skin. In Dermatology in general medicine. T.B. Fitzpatrick, editor. McGraw-Hill. New York, New York, USA. 66-84.

29. Ashkenazi, A., and Dixit, V.M. 1998. Death receptors: signaling and modulation. Science. 281:1305-1308.

30. Nagata, S. 1997. Apoptosis by death factor. Cell. 88:355-365.

31. Saunders, N.A., and Jetten, A.M. 1994. Control of growth regulatory and differentiation specific genes in human epidermal keratinocytes by IFN $\gamma$. Antagonism by retinoic acid and transforming growth factor $\beta 1$.J. Biol. Chem. 269:2016-2022.

32. Foster, C.A., et al. 1990. Human epidermal T cells predominantly belong to the lineage expressing $\alpha / \beta$ T cell receptor. J. Exp. Med. 171:997-1013.

33. Bell, E.B., Sparshott, S.M., and Bunce, C. 1998. CD4 ${ }^{+}$T cell memory, CD45R subsets and the persistence of antigen-a unifying concept. Immunol. Today. 19:60-64.

34. Crabtree, G.R. 1989. Contingent genetic regulatory events in Tlymphocyte activation. Science. 270:1189-1191.

35. Dorf, M.E., and Benacerraf, B. 1984. Suppressor cells and immunoregulation. Annu. Rev. Immunol. 2:127-157.

36. Lynch, D.H., Ramsdell, F., and Alderson, M.R. 1995. Fas and Fas ligand in the homeostatic regulation of immune responses. Immunol. Today. 16:569-572.

37. Pronk, G.J., Ramer, K., Amiri, P., and Williams, L.T. 1996. Requirement of an ICE-like protease for induction of apoptosis and ceramide generation by REAPER. Science. 271:808-810
38. Ramsdell, F., Seaman, M.S., Miller, R.E., Tough, T.W., and Alderson, M.R. 1994. gld/gld mice are unable to express a functional ligand for Fas. Eur. Immunol. 24:928-933.

39. Sallusto, F., Mackay, C.R., and Lanzavecchia, A. 1997. Selective expression of the eotaxin receptor CCR3 by human T helper 2 cells. Science. 277:2005-2007.

40. Trinchieri, G. 1994. Interleukin-12: a cytokine produced by antigen-presenting cells with immunoregulatory functions in the generation of $\mathrm{T}$ helper cells type 1 and cytotoxic lymphocytes. Blood. 84:4008-4027.

41. Scheynius, A., et al. 1992. Expression of interferon- $\gamma$ receptors in normal and psoriatic skin. J. Invest. Dermatol. 98:255-258.

42. DeBruin-Weller, M.S., Knol, E.F., and Bruijnzeel-Koomen, C.A.F.M. 1999. Atopy patch testing-a diagnostic tool? Allergy. 54:784-791.

43. Wrone-Smith, T., et al. 1997. Keratinocytes derived from psoriatic plaques are resistant to apoptosis compared with normal skin. Am.J. Pathol. 151:1321-1329.

44. Thompson, C.B. 1995. Apoptosis in the pathogenesis and treatment of disease. Science. 267:1456-1462.

45. Watanabe-Fukunaga, R., et al. 1992. The cDNA structure, expression, and chromosomal assignment of the mouse Fas antigen. J. Immunol. 148:1274-1280.

46. Tagawa, Y.I., Kakuta, S., and Iwakura, Y. 1998. Involvement of Fas/Fas ligand system-mediated apoptosis in the development of concanavalin A-induced hepatitis. Eur. J. Immunol. 28:4105-4113.

47. Sayama, K., Yonehara, S., Watanabe, Y., and Miki, Y. 1994. Expression of Fas antigen on keratinocytes in vivo and induction of apoptosis in cultured keratinocytes. J. Invest. Dermatol. 103:330-334.

48. Matsue, H., Kobayashi, H., Hosokawa, T., Akitaya, T., and Ohkawara, A. 1995. Keratinocytes constitutively express the Fas antigen that mediates apoptosis in IFN- $\gamma$ cultured keratinocytes. Arch. Dermatol. Res. 287:315-320.

49. Griffith, T.S., Brunner, T., Fletcher, S.M., Green, D.R., and Ferguson, T.A. 1995. Fas ligand-induced apoptosis as a mechanism of immune privileged sites. Science. 270:1189-1191.

50. Barker, J.N.W.N., Mitra, R.S., Griffiths, C.E.M., Dixit, V.M., and Nickoloff, B.J. 1991. Keratinocytes as initiators of inflammation. Lancet. 337:211-214

51. Nickoloff, B.J. 1988. The role of gamma interferon in epidermal trafficking of lymphocytes with emphasis on molecular and cellular adhesion events. Arch. Dermatol. 124:1835-1843.

52. Viard, I., et al. 1998. Inhibition of toxic epidermal necrolysis by blockade of CD95 with human intravenous immunoglobulin. Science. 282:490-493.

53. Liu, C., Walsh, C.M., and Young, J.D.E. 1995. Perforin: structure and function. Immunol. Today. 16:194-201.

54. Smyth, M.J., and Trapani, J.A. 1995. Granzymes: exogeneous proteinases that induce target cell apoptosis. Immunol. Today. 16:202-206.

55. Henkart, P.A. 1994. Lymphocyte-mediated cytotoxicity: two pathways and multiple effector molecules. Immunity. 1:343-350.

56. Kemeny, D.M. 1998. CD8 ${ }^{+}$T cells in atopic disease. Curr. Opin. Immunol. 10:628-633

57. Hamid, Q., Boguniewicz, M., and Leung, D.Y. 1994. Differential in situ gene expression in acute versus chronic atopic dermatitis. J. Clin. Invest. 94:870-876

58. Hamid, Q., et al. 1996. In vivo expression of IL-12 and IL-13 in atopic dermatitis. J. Allergy Clin. Immunol. 98:225-231.

59. Fujimura, T., et al. 1997. Conversion of the $\mathrm{CD}^{+} \mathrm{T}$ cell profile from $\mathrm{T}(\mathrm{H} 2)$-dominant type to $\mathrm{T}(\mathrm{H} 1)$-dominant type after varicella-zoster virus infection in atopic dermatitis. J. Allergy Clin. Immunol. 100:274-282.

60. Haake, A.R., and Polakowska, R.R. 1993. Cell death by apoptosis in epidermal biology. J. Invest. Dermatol. 101:107-112.

61. Weedon, D., Searle, J., and Kerr, J.F.R. 1979. Apoptosis. Am. J. Dermatopathol. 1:133-144.

62. Stark, H.J., Baur, M., Breitkreuz, D., Mirancea, N., and Fusenig, N.E. 1999. Organotypic keratinocyte cocultures in defined medium with regular epidermal morphogenesis and differentiation. J. Invest. Dermatol. 112:681-691. 